\title{
Le Roux v Dey and Children's Rights Approaches to Judging
}

\section{Couzens*}

\section{P.E.R}

Pioneer in peer-reviewed, open access online law publications

Author

Meda Couzens

Affiliation

University of the KwaZulu-Natal South Africa

Email

\section{Couzensm@ukzn.ac.za}

Date of submission

23 September 2017

Date published

17 January 2018

\section{Editor Prof C Rautenbach}

How to cite this article

Couzens M "Le Roux v Dey and Children's Rights Approaches to Judging" PER / PELJ 2018(21) DOI

http://dx.doi.org/10.17159/17273781/2018/v21i0a3075

\section{Copyright}

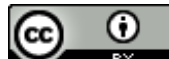

DOI

http://dx.doi.org/10.17159/1727 3781/2018/v21i0a3075

\begin{abstract}
The South African jurisprudence on the rights of children is vibrant and generally progressive, and is supported by an enabling constitutional and statutory framework. The majority decision in Le Roux v Dey 20113 SA 274 (CC), however, ignores the rights of children, and this is in stark contrast to some of the minority judgments in the same case. This contrast is surprising, considering that all of the judges applied the same legal framework. With reference to an emerging interest in defining children's rights approaches to judging, this article critically analyses the majority and minority judgments, and establishes their vulnerabilities and strengths as children's rights judgments. In the process, suggestions are made in relation to defining a children's rights approach to judging.
\end{abstract}

\section{Keywords}

Children's rights; best interests of the child; children's rights approaches to judging. 


\section{Introduction}

Litigating children's rights is no longer a novelty in South Africa. In an enabling constitutional and statutory context, ${ }^{1}$ courts are often called on to decide matters concerning children. Much progress has been made through litigation in terms of individual outcomes for children and in relation to the rights of children generally. ${ }^{2}$ One question arises nonetheless, and it is whether the formal legal protection (constitutional and statutory) cemented through a vibrant children's rights jurisprudence has led to judges embracing a children's rights perspective or approach to adjudication. The concern is that while a general legal framework for the protection of the rights of children exists, judges may not give such rights sufficiently careful consideration.

This concern is perhaps best understood in a historical context. ${ }^{3}$ The modern preoccupation with the legal protection of children started as a concern for their physical and emotional protection. From a legal perspective, and in broad terms, this translated into the legal recognition (through statute or common law) of child welfare as a principle guiding decision making concerning children. Decisions in selected matters (usually family law or child protection) centred on the "welfare principle", which was later replaced to a certain extent with the concept of "the best interests of the child". 4 While both the "welfare" and the "best interests" notions purported to put the children's welfare at the centre of the decision making, the very wide discretion enjoyed by courts, the adult perspective which dominated the process, and concerns that the welfare assessment served the interests of the adults more than genuinely promoting the interests of children have led to concerns about the ability of the welfare approach to

* Meda Couzens. Law (Cluj-Napoca), MA (Bucharest), LLM (London), MChPr (UKZN, Durban). Honorary research fellow School of Law, University of KwaZulu-Natal, Durban, South Africa. Work on this contribution started as a part of the Children's Rights Judgments Project (hereafter the CRJP) initiated by Professors Helen Stalford and Kathryn Hollingsworth of the University of Liverpool and the University of Newcastle respectively. I am grateful for their support and for the thoughtprovoking discussions at the workshops in Liverpool (March 2015) and Cardiff (April 2016). The other contributions to the project are published in Stalford, Hollingsworth and Gilmore Rewriting Children's Rights Judgments. I am also grateful for the input received from Ms Willene Holness and Associate Professor Ed Couzens. Any mistakes are mine. Email: Couzensm@ukzn.ac.za

$1 \quad$ There are numerous legal instruments which protect the rights of children in South Africa, starting with the Constitution of the Republic of South Africa, 1996 (hereafter the Constitution), especially its s 28, and specialist legislation such as the Children's Act 38 of 2005 and the Child Justice Act 75 of 2008, to name but a few.

2 Skelton "South Africa" 13.

3 For a review of the historical and theoretical development of children's rights, see Human "Theory of Children's Rights" 243.

$4 \quad$ This shift in terminology (and to a certain extent substance) has occurred under the influence of the UN Convention on the Rights of the Child (1989). 
serve children. ${ }^{5}$ With the substantial development in human rights protection and the penetration of rights into many aspects of the socio-legal landscape, child-related matters also came to be conceptualised in a rights framework. The legal endorsement of the rights of children presented an opportunity to address some of the shortcomings of a "welfare approach" by introducing more structure and transparency into decision-making concerning children. ${ }^{6}$ The premise of this reasoning is that the rigorous application of technical legal rules (ie the human rights) would lead to a positive change in judicial decision-making. The UN Convention on the Rights of the Child, 1989 and the African Charter on the Rights and Welfare of the Child, 1990 have contributed to this process by giving legal contour to the rights of children internationally. In South Africa the Constitution of the Republic of South Africa, 1996 (hereafter the Constitution) has played an essential role by legitimising reliance on the rights of children in the legal discourse and by contributing substantially to the effective protection of children's rights.

However, has this shift toward thinking about children in a rights framework led to courts adopting a children's rights perspective, ${ }^{7}$ and consequently delivering to children the benefits which the rights framework promised? Have legal instruments protecting the rights of children led to courts embracing a sustained (and sustainable) approach to decision-making, in which the rights of children are used as a matter of legal obligation rather than on a discretionary basis, dependent on the personal openness of individual judges toward the rights of children? Questions of this nature raise the inevitable (and inherently wide) question as to what constitutes a children's rights approach or perspective to judging.

Like the concept of children's rights in the past, a "children's rights approach" to judging is a concept in search of a definition. ${ }^{8} \mathrm{~A}$ fundamental issue which still needs to be clarified is to what extent courts can legitimately have a "perspective" or embrace a certain "approach" without becoming advocates for a cause and consequently compromising their impartiality.

5 About concerns in relation to welfare decision-making, see Fortin Children's Rights and the Developing Law 22.

$6 \quad$ For critical views on the application of the welfare principle, especially by English courts, see Fortin Children's Rights and the Developing Law 292.

$7 \quad$ The preoccupation of this contribution is with the children's rights approach being taken by judges. This does not mean that such an approach cannot or should not be taken by other decision-makers. It is possible nonetheless that a children's rights approach may require different things of different decision makers, depending on their constitutional functions (ie the legislature, the executive, the judiciary, independent human rights institutions, local authorities, etc).

8 In 1973 Hillary Rodham argued that children's rights were concepts in search of a definition (as cited in Tobin "Development of Children's Rights" 25. The aim of the CRJP was to generate a discussion of the issue and establish some parameters for defining a "children's rights approach/perspective". 
Much probably depends on a comprehensive definition of the elusive phrase "children's rights approach/perspective", ${ }^{9}$ which this current article does not aim to formulate.

Instead, prompted by the jurisprudence of the South African Constitutional Court, two related questions are raised in a quest to "peel away" some of the layers of this complex phrase and make a modest contribution to giving contour to its meaning. The questions addressed here are whether a children's rights approach is inherently present in judgments with a childfavourable outcome; and whether a children's rights perspective arises as a matter of necessity from children's rights being entrenched in constitutions or children's rights statutes. Both questions are answered in the negative, confirming what has been said by other commentators ${ }^{10}$ - that something more is needed than an enabling legal framework (international or national) to secure a children's rights approach to judging.

Acknowledging once more that defining a children's rights approach is work in progress, the working definition of a children's rights perspective to judging in this piece entails an approach in which the children's rights are acknowledged and applied when a decision has the potential to limit them, ${ }^{11}$ and they are treated with the legal rigour owed to all legal concepts including, where necessary, an understanding and a determination of the substantive content of the rights at stake. ${ }^{12}$ The absence in this primitive definition of a reference to a child-favourable outcome is deliberate. In the view of the present writer, a child rights approach is not an inherent feature of judgments written from a children's rights perspective. Arguably, a child rights imprimatur is given by the reasoning of the court, rather than by an outcome which may be intrinsically linked to the facts of a case.

There may be a temptation to dismiss the elements of the above definition as the self-evident tasks of courts in all matters, child-related or not. This contribution will show, however, that such features are not to be taken for

$9 \quad$ Tobin "Development of Children's Rights" 26 uses a different terminology: he writes of a "'rights-based' approach to matters dealing with children" and acknowledges the elusive meaning of the phrase.

10 Tobin "Development of Children's Rights" 36.

11 Arguably, this approach finds support in ss 7(2) and 8(1) of the Constitution, which provide for the obligation of the state to "respect, protect, promote and fulfil the rights in the Bill of Rights", and stress the binding nature of the Bill of Rights for the courts, inter alia. However, a determination that children's rights are relevant in a particular dispute may not be easy to make, especially when the matter concerns children indirectly and the children are not involved in the litigation.

12 Tobin mentions the understanding of the legal content of a right as one of the features of a child rights approach, but in a wider decision-making framework (Tobin "Development of Children's Rights" 37). This feature is apposite for a children's rights approach by courts and is consequently included by the present author in the above definition. 
granted in what remains the developing field of children's rights. Acknowledging that children's rights are engaged or relevant in concrete disputes requires judges to look deeper into the matters before them. At times this involves considering the position of children who are not parties to disputes or anticipating the consequences of litigation on them. It may also require that when judges apply the law, especially in those fields not within the habitual scope of application of the rights of children, they ask themselves (to the extent that they are constitutionally authorised to do so) ${ }^{13}$ if the law is sufficiently adapted to respond to the position of children as legal subjects that are different from adults.

The objectives of this article are pursued by analysing, from the perspective of the above definition, the approaches taken by the majority in Le Roux $v$ $D e y^{14}$ and Yacoob J's dissent (in which he was joined by Skweyiya J) in the same case. The reasoning of the majority marginalises the rights of children, and it is clearly not a judgment in which a children's rights approach has been taken. By contrast, Yacoob J's judgment is a child-centred judgment, but, arguably, not necessarily a judgement written from a children's rights perspective. While Yacoob $\mathrm{J}$ acknowledges the importance of the rights of children and their relevance to the dispute, there is some lack of clarity in how rights are used as well as their content which prevents this judgment from being the landmark children's rights judgment which it could have otherwise become.

This contribution is structured as follows. Part 2 provides a brief presentation of the case and is followed in part 3 by a presentation of the judgments written by the Constitutional Court judges. Part 4 discusses the importance of the case for the development of children's rights, and is followed in part 5 by a critique of the judgments from a children's rights perspective. Conclusions are drawn in part 6 , where observations are made in relation to the contribution of this case to understanding what a children's rights approach is or ought to be.

\section{Brief presentation of the case}

The case concerns a prank played by three teenaged schoolchildren (one aged 15-and-a-half, and two aged 17) on the deputy principal of their high school in Pretoria. They manipulated a picture downloaded from the internet by superimposing the heads of the deputy principal (Dr Dey) and the

13 In a South African constitutional context, judges are authorised and even required to do so because the Bill of Rights (which includes the rights of children in s 28) "applies to all law, and binds the legislature, the executive, the judiciary and all organs of state" (s 8(1) of the Constitution).

14 Le Roux v Dey (Freedom of Expression Institute and Restorative Justice Centre as Amici Curiae) 20113 SA 274 (CC) (hereafter Le Roux). 
principal on a picture representing two naked men in a position suggestive of sexual activity. The genitals of the two men were covered by the image of the school crest. The picture was crudely executed, and it was clear that the naked bodies in the picture were not those of the teachers. The picture was distributed by one of the boys via a cell phone and one of the recipients placed the picture on the school noticeboard. The boys were subjected to disciplinary proceedings at school and to pre-trial diversion (in the form of community work) for crimen injuria against $\mathrm{Dr}$ Dey.

The deputy principal also sued the boys for two common law delicts: defamation (injury to one's reputation) and infringement of his dignity (injury to his feelings of self-worth). The central issue was whether the image manipulated by the defendants was defamatory of Dr Dey and injured his dignity. Defamation has been defined as the wrongful and intentional publication of a defamatory statement. ${ }^{15}$ For a publication (a picture in this case) to be defamatory it has to have a meaning likely to lower the esteem which the plaintiff enjoys in the eyes of others. An action for injury to one's feelings (the second cause of action of the plaintiff) protects a person's feelings of self-worth against deliberate and wrongful acts which impair one's dignity. ${ }^{16}$ For such action to succeed, the plaintiff must feel insulted by the conduct of the defendant, and the conduct of the defendant must also be seen as insulting by the reasonable observer.

The High Court found the boys liable for both delicts, ${ }^{17}$ while a majority in the Supreme Court of Appeal (SCA) found the boys liable for defamation but not for the dignity claim. The boys appealed the SCA judgment to the Constitutional Court (the Court). Two amici made submissions to the Court: the Freedom of Expression Institute (FXI) and the Restorative Justice Centre (RJC).

\section{The judgements of the Constitutional Court}

Four judgments were written by the Constitutional Court judges, a clear indication of the contentiousness of the issue.

15 Le Roux para 84 (fn omitted) citing Khumalo v Holomisa 20028 BCLR 771 (CC) para 18.

16 In this context, dignity has a narrower meaning than its constitutional counterpart, and refers to one's feelings of self-worth (Le Roux para 138).

17 Children aged 7 to 14 are considered doli incapax (a rebuttable presumption), and children between the ages of 14 and 18 are considered doli capax (Schäfer "Division E: Young Persons" paras E74 and E75). In Le Roux, the children were considered doli capax. 


\subsection{The majority judgment}

Brand AJ for the majority (with Ngcobo CJ, Moseneke DCJ, Khampepe J, Mogoeng $\mathrm{J}$ and Nkabinde $\mathrm{J}$ concurring) found the image defamatory and the defendants liable for defamation but not for injury to Dr Dey's dignity. To reach its conclusions the Court applied the existing defamation law. The meaning of the picture and its alleged defamatory character were to be evaluated according to the understanding of a "reasonable person of ordinary intelligence". ${ }^{18}$ On the meaning of the picture, the Court decided that although no reasonable person would believe that the naked bodies belonged to the teachers, there was an association made/drawn between them and the immoral behaviour depicted therein. That association made the picture defamatory because it was meant to tarnish the reputation of the teachers, to belittle them, to expose them to contempt and disrespect, and to ridicule them. ${ }^{19}$

The majority rejected various arguments aimed at persuading the Court to develop and apply the law of defamation in a way which was more sensitive to the defendants' minority. For example, it dismissed arguments that the picture was a crude manipulation and that a reasonable observer would not believe it to represent the teachers; ${ }^{20}$ and that the picture was a joke, which meant that the defendants lacked the intention to defame. ${ }^{21}$ The fact that the image was created by school children was not an irrelevant consideration, as the reasonable observer would know that children often poke fun at their teachers. ${ }^{22}$ However, when a joke "becomes hurtful; when it represents the teacher as foolish, ridiculous and unworthy of respect"23 a certain line is crossed, ${ }^{24}$ and the joke becomes defamatory. The FXI sought to persuade the Court to develop the defences against wrongfulness so as to include the right of children to experiment with satire, as part of their right to freedom of expression. ${ }^{25}$ The majority found it "unnecessary" to deal with this argument at length, because it was based on a "rather radical ground", which "derives no support from our law as it stands" 26 and because it was not pleaded at the trial. ${ }^{27}$ The only aspect on which the minority status of the defendants seemed to have carried any weight for the majority was in their

Le Roux para 39.

Le Roux paras 107, 109.

Le Roux para 103.

Le Roux paras 113-115.

Le Roux para 117.

Le Roux para 119.

Le Roux para 118.

Le Roux paras 120, 123.

Le Roux para 127.

Le Roux para 127. 
acquiescence to the remedy developed by Froneman $\mathrm{J}$ and Cameron $\mathrm{J}$ (discussed below).

\subsection{The minority judgments}

Yacoob $\mathrm{J}$ found that the boys were not liable for any of the delicts. To decide that the image was not defamatory, Yacoob $\mathrm{J}$ (concurred with in a separate judgment by Skweyiya J) decided that simply relying on the "reasonable man" test is not apposite and that the Court had to consider "all relevant circumstances for the purposes both of interpreting the image and for deciding whether its impact is defamatory". ${ }^{28}$ The image had to be construed constitutionally, which implies considering the relevant rights to dignity and privacy of Dr Dey, and freedom of expression and the rights of children. ${ }^{29}$ In dealing with the rights of children, Yacoob $\mathrm{J}$ set out some of the requirements arising from previous children's rights cases. ${ }^{30}$ These constitutional considerations will have a bearing on how the Court should proceed if an image can reasonably be interpreted either as defamatory or as not defamatory. ${ }^{31}$ According to Yacoob J, the current law allows a child to be held liable for defamation even when a child-friendly interpretation of a picture is reasonably possible. ${ }^{32}$ This approach was incompatible with the rights of children, who would not receive adequate protection, and whose "vulnerability and weakness are not sufficiently catered for in that approach". ${ }^{33}$ To bring the law in line with the constitutional requirements, he proposed the adaptation of a constitutional law rule for the interpretation of statutes, suggesting that when both defamatory and non-defamatory interpretations are possible "the courts should prefer that interpretation which does not hold the child liable provided that the construction is not strained". ${ }^{34}$

In construing the image from the perspective of the reasonable observer, Yacoob $\mathrm{J}$ relied on factors which emphasised the uniqueness of the children's position, ${ }^{35}$ including the fact that the image was a challenge to the school authority, and was not directed at Dr Dey personally. ${ }^{36}$ The

\footnotetext{
$28 \quad$ Le Roux para 43.

$29 \quad$ Le Roux para 44.

30 Le Roux paras 49-50. The cases relied on by Yacoob J are Centre for Child Law $v$ Minister of Justice and Constitutional Development 20096 SA 632 (CC) and Director of Public Prosecutions, Transvaal $v$ Minister of Justice and Constitutional Development 20094 SA 222 (CC).

$31 \quad$ Le Roux para 51.

$32 \quad$ Le Roux para 52.

$33 \quad$ Le Roux para 53.

$34 \quad$ Le Roux para 54.

$35 \quad$ Le Roux para 57.

$36 \quad$ Le Roux para 65. Also see the "reasoning of a reasonable person" according to Yacoob J at para 64.
} 
reasonable observer has to consider, in respect of images created by children, that the "nature of the expression with which we are concerned is integrally part of the process of their development and the process of their education", ${ }^{37}$ and that

... an over-emphasis on the rights of a good name and reputation of a deputy principal in relation to the rights of powerless children will be counterproductive and will be harmful to the interests of children. ${ }^{38}$

Froneman $\mathrm{J}$ and Cameron $\mathrm{J}$ wrote a joint separate judgment, in which they found the boys liable for breach of dignity, but not for defaming the plaintiff. They shared Yacoob J's view that the image was not defamatory, but found that the defendants injured the plaintiff's dignity, in that he felt affronted by his association with naked bodies, indecency and homosexuality. ${ }^{39}$ The two judges reduced the quantum of damages awarded by the lower courts, and developed the common law so as to include apology as a remedy for defamation. ${ }^{40}$ Their reasoning on remedies does not refer to the rights of children, but rather to restorative justice and fairness principles. ${ }^{41}$

\section{The importance of the case for the rights of children}

Le Roux was the first case in which South African courts engaged with defamation by children. The case brought the law of defamation, which focuses on the victim and where there is "little scope for treating the child defendant differently from the adult defendant", ${ }^{42}$ face to face with children's constitutional rights and a jurisprudence generally sensitive to the rights of children. ${ }^{43}$ The case was also a first to see the Court engage with children's right to freedom of expression, and it did so amidst concerns about school discipline. Le Roux has potential consequences for the future, considering that wide access to means of electronic communication creates new opportunities for children to express themselves, including in ways which may harm others. ${ }^{44}$

A mix of reactions was generated by the judgments. ${ }^{45}$ Surprisingly, the case has not received much attention from children's rights scholars. Mills has

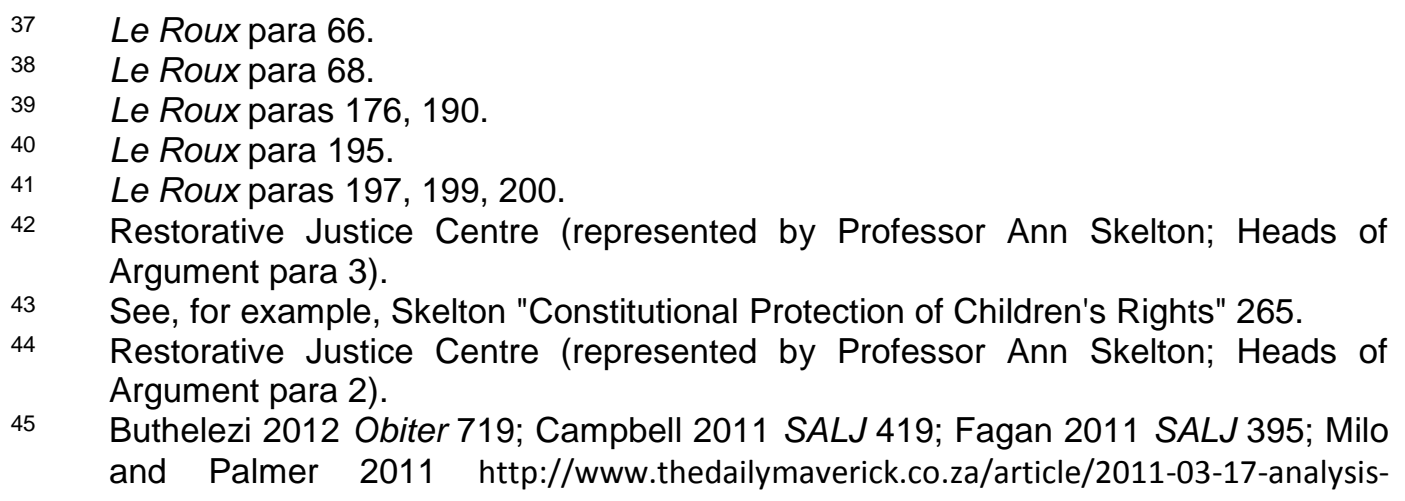

45 Buthelezi 2012 Obiter 719; Campbell 2011 SALJ 419; Fagan 2011 SALJ 395; Milo and Palmer 2011 http://www.thedailymaverick.co.za/article/2011-03-17-analysis- 
comprehensively criticised the majority for ignoring the best interests of the child in section 28(2) of the Constitution, ${ }^{46}$ and Sloth-Nielsen and Kruuse have written critically of the contrast between the majority judgment and the tradition of the South African courts to give special protection to children. ${ }^{47}$

\section{A children's rights critique of the judgments}

The critical question which dominates Le Roux is whether, in the light of children's constitutional rights, children who are alleged to have defamed others should be treated differently from adults who defame. To this question the majority and minority gave contrasting answers.

\subsection{A critique of the majority judgment}

From a children's rights perspective, the major problem with Brand AJ's judgment is the absence of any serious consideration of the rights of children, which resulted in the defendants being treated like adults. While for Yacoob $\mathrm{J}$ the rights of children took centre stage, the majority simply found that they were "not irrelevant". ${ }^{48}$ The reasonable observer is construed exclusively based on adult standards, and no attention is given to the fact that the audience consisted of children, apart from mentioning that maintaining discipline at school was important and that the image undermined that endeavour. As mentioned above, all attempts to move the Court to develop the common law of defamation to take the rights of children into consideration were resisted by the majority of the judges.

This is contrary to the Court's solid children's rights jurisprudence, which creates an informal expectation that children will be given a special legal treatment. The reasons for the marginalisation of the rights of children by the majority in Le Roux are not readily apparent. The majority was of the view that children's right to freedom of expression (section 16 of the Constitution) was insufficiently canvassed before the courts to enable a balancing between "the freedom of expression of schoolchildren" and "the dignity of teachers - including their reputation". 49

schoolboy-scandals-and-defamation-in-sa-quo-vadis; Neethling and Potgieter 2011 Obiter 721; Stubbs 2013 Stell LR 377; De Vos 2011 http://constitutionallyspeaking.co.za/is-the-reasonable-person-a-homophobicprude/.

$46 \quad$ Mills 2014 SALJ 847.

47 Sloth-Nielsen and Kruuse 2013 Int'l J Children's Rts 672.

$48 \quad$ Le Roux para 82.

$49 \quad$ Le Roux paras 127, 128. 
Section 28(2) of the Constitution (the best interest's provision) would however have been ${ }^{50}$ an alternative legal ground on which to base the insertion of child-focused aspects into the majority's reasoning (and one which, arguably, has provided a base from which procedural requirements can be regarded less stringently). ${ }^{51}$ In the South African law, section 28(2) of the Constitution plays a triple role. It is a right in itself, a principle of interpretation for the rights in section 28(1) of the Constitution (the more specific rights of the child), and a tool for establishing the scope of the constitutional rights of other rights holders and their potential limitations. ${ }^{52}$ The distinctions and the overlaps among these functions are yet to be clarified, ${ }^{53}$ but in prior cases, regardless of the technique used, section 28(2) of the Constitution has been associated with a special and a more favourable legal treatment for children. ${ }^{54}$ While the best interests standard permeates the reasoning of Yacoob $\mathrm{J}$, it is at least surprising to see it completely side-lined in the reasoning of the majority.

The opacity of the majority's position vis-à-vis the application of section 28(2) of the Constitution leaves room for speculation. Did the majority consider that section 28(2) of the Constitution was not applicable, as deemed possible by the Court in $S v M ?^{55}$ Such reasoning would have been difficult to justify in a case concerning children directly, rather than indirectly as was the case in $S \vee M$, where the issue was first raised. Was the majority concerned that the application of section 28(2) of the Constitution would have required it to prioritise automatically the interests of the children at the expense of Dr Dey's legitimate interests? Such concern would ignore that the Court's own jurisprudence shows that "paramount importance" does not mean that children's interests trump all other interests. ${ }^{56}$ Arguably, a possible reason for the majority's reluctance to engage with section 28(2) of the Constitution was that the law of defamation is poorly equipped to

50 Section 28(2) of the Constitution reads: "A child's best interests are of paramount importance in every matter concerning the child".

$51 \quad A D \vee D W$ (Centre for Child Law as Amicus Curiae; Department for Social Development as Intervening Party) 20083 SA 183 (CC) (hereafter AD v DW) para 55; Van der Burg v National Director of Public Prosecutions 20122 SACR 331 (CC) (hereafter Van der Burg) para 68. Admittedly, in a case like Le Roux, it may be pushing it too far to argue that a "relaxation" of procedural rules on the basis of the best interests would have dispensed with the need to present comprehensive arguments on the issue.

52 Skelton "Constitutional Protection of Children's Rights".

53 Bonthuys 2006 IJLPF 23; Couzens 2013 SALJ 672.

$54 \quad$ For a more detailed review of the jurisprudence of the Constitutional Court on s 28(2) of the Constitution, see Couzens "Contribution of the South African Constitutional Court" 521.

55 S v M (Centre for Child Law as Amicus Curiae) 20083 SA 232 (CC) (hereafter S v M) para 25.

56 De Reuck v Director of Public Prosecutions (Witwatersrand Local Division) 200312 BCLR 1333 (CC); $S$ v M. 
accommodate children's specificities, unlike family law or juvenile justice, where the common law makes allowance for such. Further, much of the normative power of section 28(2) of the Constitution has been contoured in public law cases directed against the state, or in family law and child protection cases. Le Roux raised a different, more difficult legal issue: the horizontal application of section 28(2) of the Constitution to matters other than family law or child protection, which the majority refrained from addressing.

In the end, whatever the discomfort of the majority with the application of section 28(2) of the Constitution, it sits badly with the Court's position that the rights in section 28 of the Constitution "are an enforceable precept determining how officials and judicial officers should treat children" ${ }^{57}$ and that "the courts are essentially guarding the best interests of a child, not simply settling a dispute between litigants". ${ }^{58}$

\subsection{A critique of Yacoob J's judgment}

Yacoob J's minority judgment is clearly a child-focused judgment whose outcome is favourable to children. Does this make it, however, a children's rights judgment? The judgment has been met with approval by children's rights academics, ${ }^{59}$ but is it all well with the manner in which Yacoob $\mathrm{J}$ approached the issues?

As mentioned in the introduction, defining a children's rights perspective to legal reasoning is work in progress, but regardless of how the concept is defined children's rights judgments cannot be less rigorous than other judgments. Arguably Yacoob J's judgment may be problematic in this regard. The judge talks about children's freedom of expression but gives little formal attention to a child-specific legal content of this right. Instead, Yacoob J's judgment ends up relying heavily on the normative power of section 28(2) of the Constitution. It is submitted that section 28(2) of the Constitution should not be used as an "easy way out" of difficult legal issues, and decisions based on it should not be less rigorous than other judgments. It is a loss to the development of the rights of children that Yacoob J did not use his child-focused observations to develop the legal content of children's rights to freedom of expression rather than to "pad" his best interests reasoning. Further, Yacoob $\mathrm{J}$ does not identify the specific right or rights which he applies. Instead, he refers to several constitutional rights - dignity and equal worth; 60 children's right to be cared for at the school (section

57

Centre for Child Law v Minister of Justice and Constitutional Development 20096 SA 632 (CC) para 25 (fn omitted).

$58 \quad A D \vee D W$ para 55.

59 Mills 2014 SALJ 847; Sloth-Nielsen and Kruuse 2013 Int'I J Children's Rts 672.

$60 \quad$ Le Roux para 49. 
28(1)(b) of the Constitution); and to be protected against maltreatment, neglect, abuse and degradation (section 28(1)(d) of the Constitution) ${ }^{61}$. without giving them focused attention or explaining their relevance to the case. This observation may be criticised as being legally formalistic, but it is necessary to point out that the other judges found it necessary to be more specific. As Skweyiya J correctly notes, none of the more specific rights in section 28(1) of the Constitution were directly relevant. Thus, reliance on section 28(2) was warranted. ${ }^{62}$

To correctly rely on section 28(2) of the Constitution applied independently, Yacoob $J$ should arguably have identified the entitlements arising independently therefrom, and then apply them to the context. In the present writer's view, this was not done, and as a consequence Yacoob J's reasoning exposes one of the weaknesses in the South African children's rights jurisprudence: the absence of clarity in relation to the use of the best interests of the child provision in the Constitution as a self-standing right. ${ }^{63}$ It may be that, like the majority, Yacoob $\mathrm{J}$ thought that procedural reasons prevented him from considering the application of section 15 of the Constitution and giving it a child-specific content. If that was so, Yacoob J does not say it. It would have done more service to the cogency of his judgment to acknowledge the issue than to gloss over it.

Paradoxically, although Yacoob J's judgment is child-focused, this Justice's use of children's rights is not the most effective. Children's rights are used as part of the context in which the alleged defamatory picture is to be assessed (its meaning and its defamatory character). This, arguably, does not capitalise on the full constitutional force of these rights: they are part of the context, but their normative impact is unclear. Skweyiya $\mathrm{J}$ seems to attempt a clarification of the normative impact of the rights of children by pointing out that section 28(2) of the Constitution

... forms the basis and starting point from which the matter is to be considered. Once the considerations relevant to this foundation are clearly cemented, one can then begin to examine the other rights that enter the balance ...64

Skweyiya J's judgment is, however, too short for a full and convincing application of this approach.

One of the surprising aspects of Yacoob J's reasoning is that although effectively this Justice develops the common law of defamation by relying

$61 \quad$ Le Roux para 57.

62 Le Roux para 120.

63 Bonthuys 2006 Int'l J Children's Rts 23; Couzens 2013 SALJ 672.

64 Le Roux para 211. See also Teddy Bear Clinic for Abused Children v Minister of Justice and Constitutional Development 20142 SA 168 (CC) paras 38-41 (hereafter Teddy Bear Clinic). 
on the rights of children, this is not explicitly acknowledged. Nowhere in his judgment is there a reference to sections $8(3)^{65}$ or $39(2)^{66}$ of the Constitution, although these are both sections that would have bolstered Yacoob J's reasoning and, perhaps, have allowed him to gather more support for his judgment from the other members of the Court. ${ }^{67}$

To conclude this point, while Yacoob J's judgment is a child-focused judgment, it may fall short of being a children's rights judgment because of his insufficiently clear application of children's rights. With respect, Yacoob $\mathrm{J}$ may have engaged in a similarly problematic reasoning in $C \mathrm{v}$ Department of Health and Social Development, Gauteng, ${ }^{68}$ where he relied heavily on section 28(2) of the Constitution, without giving much formal attention to the more specific section 28(1)(b) of the Constitution. In the current state of the law, this approach is not necessarily incorrect as there is no precedent requiring that the independent application of section 28(2) of the Constitution is subsidiary to the application of more specific rights in section 28(1) of the Constitution. However, the shunning of a right that is directly relevant in favour of a more general provision requires some justification.

Interesting criticism of Yacoob J's judgment comes from Buthelezi, who argues that Yacoob $\mathrm{J}$ was "misdirected by his unwarranted bias towards the children's rights", 69 and that the children in casu were not vulnerable, nor was their dignity at stake. While this criticism may be misplaced, ${ }^{70}$ it nonetheless prompts reflection on some basic yet complex issues pertaining to the legal treatment of children. Is a children's rights approach a matter of "unwarranted bias", as feared by Buthelezi, or a "mantra for the converted" who are deliberately oblivious to an orderly application of the law? Are judgments like $C v$ Department of Health, Gauteng and Yacoob

65 Section 8(3) of the Constitution reads: "When applying a provision of the Bill of Rights to a natural or juristic person in terms of subsection (2), a court (a) in order to give effect to a right in the Bill, must apply, or if necessary develop, the common law to the extent that legislation does not give effect to that right; and (b) may develop rules of the common law to limit the right, provided that the limitation is in accordance with section 36(1)".

66 Section 39(2) of the Constitution reads: "When interpreting any legislation, and when developing the common law or customary law, every court, tribunal or forum must promote the spirit, purport and objects of the Bill of Rights".

67 One explanation may be that Yacoob J's reasoning does not rely directly on the constitutional provisions he mentions (ss 9, 10, 28(1)(b) and (d), 28(2)) of the Constitution, but rather on previous case-law which interpreted them. Yacoob $\mathrm{J}$ might have seen his judgment as building on those precedents, which were already constitutionally infused, with no need to refer directly to the constitutional provisions which would authorise his approach.

$68 \quad$ C v Department of Health and Social Development, Gauteng 20122 SA 208 (CC).

$69 \quad$ Buthelezi 2012 Obiter 723.

70 The application of the rights of children can hardly constitute "bias" when such rights are constitutionally protected and the judges are mandated by the Constitution to protect them (ss 7(2) and 8(1) of the Constitution). 
J's judgment in Le Roux, together with the children's rights academia's failure critically to engage with them, perhaps maintaining a perception that children's rights are some sort of legal misfits? Does the frequency with which the constitutional provision on the best interests of the child is used in judgments perpetuate the perception that children's rights have a lesser "legal pedigree"? ${ }^{71}$

Tobin has noted that perspectives on the rights of children vary significantly between children's rights supporters and those for whom these rights "are not self-evident". ${ }^{72}$ For the latter, children's rights may be invisible or can be rejected. ${ }^{73}$ This is so because there is an insufficient conceptual development of children's rights which erodes their legitimacy ${ }^{74}$ and limits their appeal beyond the community of child rights supporters. Is it possible that children's rights supporters have inadvertently created a perception of bias because of the lack of critical discourse within children's rights research, ${ }^{75}$ or because of the activist perspective which children's rights research sometimes takes ${ }^{76}$

The perception of bias raised by Yacoob J's approach is clearly linked to this Justice's applying a different legal treatment to children. Yacoob $\mathrm{J}$ has done so by developing the common law of delict in order to accommodate children's special features (ie age, lack of maturity) and to reflect the constitutional obligations of the state and its institutions (including its courts) to respect and protect the rights of children. A fair criticism of such an approach, which is anchored in the Constitution, ought to be accompanied by a further inquiry into the reasons which may have prompted senior judges to develop the common law instead of mechanically applying the existing legal principles. Seen in this light, Yacoob J's reasoning does not appear as "biased" but rather as constitutionally mandated. Yacoob J's judgment invites one to question the validity of defamation law rules which allow children who are doli capax to be treated like adults, prima facie contrary to the Constitution, which recognises "the right of a child to be a child and enjoy

71 It is worth noting that heavy reliance on s $28(2)$ of the Constitution is not inevitable, and significant children's rights cases have been decided by the Constitutional Court with no reliance on this section (ie Christian Education South Africa $v$ Minister of Education 200010 BCLR 1051 (CC) (hereafter Christian Education South Africa); MEC for Education: KwaZulu-Natal v Pillay 20081 SA 474 (CC)), or by utilising it in a more structured and legally predictable fashion (Teddy Bear Clinic).

72 Tobin 2013 Int'l J Children's Rts 398.

Tobin 2013 Int'l J Children's Rts 398.

Tobin 2013 Int'l J Children's Rts 398.

Reynaert, Bouverne-De Bie and Vandevelde 2012 Int'l J Children's Rts 155.

On the tensions between the "role of a distant scientific observer, and the role of human rights advocate" played by children's rights researchers, see Hanson "Does Practice Also Work in Theory?" 636. 
special care". ${ }^{77}$ Notably, the same children would be treated differently from adults, and generally less harshly, in other areas of law. Indeed, why is it that in the field of criminal law, which deals with behaviour considered so serious as to warrant criminalisation by the state, children who are criminally responsible (regardless of their age) are given special legal treatment, but in the law of defamation, which concerns harm of a less serious nature, this special legal treatment is denied to doli capax children ${ }^{78}$ The answer is, arguably, in the legal tradition and the evolution of the South African law, which Yacoob $\mathrm{J}$ rightly questioned through the prism of children's constitutional rights, which he was entitled to do under the Constitution. ${ }^{79}$

Perhaps in the current state of the transformation of the law under the influence of the Constitution, such inquisitive assessment may require a certain degree of bias or advocacy if this is understood as a willingness on the part of judges to look further than the mechanical application of the law and to question its fitness when applied to children. Arguably, as long as the law ignores children as different legal subjects, "bias" or "advocacy approaches" may be unavoidable and to a certain degree desirable. This is so especially in a legal system where judges have legitimate control over the development of the (common) law ${ }^{80}$ and are empowered to assess the constitutionality of laws.

The second issue raised by Buthelezi's comments concerns children's vulnerability and dignity as the justification for their differential legal treatment. In South African law children are treated differently in many respects, and the case-law has created a "distinct vision of children", ${ }^{81}$ reflected in a "constitutional childhood" which encompasses "protection coupled with emancipation" and "freedom to explore blended with adult guidance and compass". ${ }^{82}$ But what the basis of this "distinct vision" is may not always be clear. Ought children to be treated differently because of their de facto vulnerability assessed on a case-by-case basis, or simply because they are different (from adults), and have a "unique worth"83 or a unique/different dignity? According to some authors, it is "[t]he special

$77 \quad S \vee M$ per Sachs J para 17.

78 In criminal law, for example, children benefit from a more favourable legal treatment (pre-trial, trial and sentencing).

79 Section 39(2) of the Constitution.

80 Other judges have utilised this constitutional power. Very recently, for example, in YG v S 2017 ZAGPJHC 290 (19 October 2017), Keightly J (concurred with by Francis $\mathrm{J}$ ) raised ex officio the constitutionality of the defence of reasonable chastisement. The two Justices declared the defence unconstitutional, and developed the common law in line with the requirements of the Constitution.

81 Sloth-Nielsen and Kruuse 2013 Int'I J Children's Rts 671.

82 Sloth-Nielsen and Kruuse 2013 Int'l J Children's Rts 672 (all quotes). Term used by Tobin 2013 Int'l J Children's Rts 407. 
vulnerability that provide[s] the justification for special protection", ${ }^{84}$ while for others there is a certain overlap between vulnerability and dignity in that children's vulnerability makes their dignity unique or different. ${ }^{85}$ While in some cases distinguishing between vulnerability and dignity as a basis for a different legal treatment may not be necessary, for children such as those in Le Roux this distinction is useful: if children are not seen as (conventionally) vulnerable, they may still qualify for a special legal treatment because of their unique dignity.

Deciding which children are vulnerable depends on how vulnerability is defined. While in the context of an uncomplicated medical treatment, for example, a competent child may not be considered vulnerable, ${ }^{86}$ a child offender, although criminally capable, remains vulnerable and subject to a different legal treatment. Further, certain forms of vulnerability are already (and readily) acknowledged by the law and the courts (ie children in need of protection, children in conflict with the law, child victims, child witnesses) while there may be a lack of agreement in relation to other forms of vulnerability. For example, the children in Le Roux might not be seen as vulnerable according to the readily accepted versions of vulnerability, but may appear as vulnerable if they are seen as part of a class of persons whose special, relevant features were ignored throughout the development of the law of defamation. This raises the further question as to whether a special legal treatment should be granted based on individual vulnerability or on the vulnerability of children as a special class of individuals. The manner in which these issues are addressed has an impact on whether the children in Le Roux ought to have received differential legal treatment.

What constitutes child-sensitive, differential legal treatment can also be contentious. In the specific context of Le Roux, would the requirements regarding delictual capacity, the crafting of a new remedy (ie an apology) and a reduction in pecuniary damages perhaps be sufficient to protect children's vulnerability or dignity in defamation law? How can child-sensitive legal responses remain mindful of other people's vulnerabilities, and how should judges balance protection with responsibility and aspirations for autonomy?

The theoretical questions raised above require more attention than can be provided here. Suffice it to say that in South Africa the case law seems to provide support for both visions (one founded on vulnerability ${ }^{87}$ and the

\footnotetext{
84 Tobin 2013 Int'l J Children's Rts 407 giving the example of medical treatment.

85 Dixon and Nussbaum 2011-2012 Cornell L Rev 553.

86 Tobin 2013 Int'I J Children's Rts 429.

87 In Centre for Child Law para 26 Cameron J talks about "children's greater physical and psychological vulnerability".
} 
other on dignity ${ }^{88}$ ), and perhaps a combination of the two. ${ }^{89}$ Judicial views have developed on a case-by-case basis in response to the circumstances of each case, and they do not reflect a unitary approach. However, judges cannot be expected to theorise about the rights of children, a task which remains mainly with academia.

\section{Conclusions}

In part 2 two questions were chosen as a focus for this contribution: Is a children's rights approach to judging inherent where the rights of children are entrenched in constitutions or children's rights statutes? The second question interrogated whether a children's rights approach is inherent in judgments with a child-favourable outcome. A "children's rights approach" was tentatively defined as an approach in which children's rights are acknowledged and applied when engaged, and are treated rigorously, with careful attention to their legal content.

In relation to the first question, the majority decision in Le Roux shows that the formal protection of the rights of children, even at the highest level (ie the constitutional level), and a solid children's rights jurisprudence do not guarantee that a children's rights approach would be taken by judges at all times. The majority in Le Roux eschewed the constitutional rights of children and avoided applying them in areas of the common law where children's rights are not often considered. ${ }^{90}$ Le Roux confirms academic views that entrenching children's rights in legal documents is insufficient to ensure their consistent application and their visibility to those for whom such rights are not "self-evident". ${ }^{91}$ Ultimately, the majority was unpersuaded that they ought to administer a different legal treatment to the children in this case and develop the law so as to accommodate such treatment.

In relation to the second question, Yacoob J's judgment, despite its many positive aspects (ie its child-friendly outcome and its child-focused conceptualisation of legal issues) might not necessarily be a children's

In $S$ v M, Sachs $\mathrm{J}$ talks about "every child [having] his or her own dignity" (para 18), which is manifested in the need to experience and develop (para 19). Also see Teddy Bear Clinic para 55; Christian Education South Africa paras 15, 50. Le Roux per Yacoob J paras 46 and 53; Le Roux per Skweyiya J para 212. See, by contrast, the ease with which the Court uses the rights of children against the state in C v Department of Health and Social Development, Gauteng 20122 SA 208 (CC); J v National Director of Public Prosecutions 2014 ZACC 13; Teddy Bear Clinic.

Tobin 2013 Int'l J Children's Rts 397. Tobin makes the point that some policy-makers and academics still manifest "a level of resistance, scepticism and uncertainty about the utility of rights for children" (Tobin "Development of Children's Rights" 26-27). Similar views have been expressed earlier by Fortin Children's Rights and the Developing Law; Human "Theory of Children's Rights" 244. 
rights judgment. This is so because of the arguably imprecise use of the rights of children. Yacoob $\mathrm{J}$ makes a good case that children ought to be treated differently, and shows that they have been so treated in the Court's own case law. What Yacoob $\mathrm{J}$ failed to do was to persuade the majority that the law either accommodates or requires that such different treatment be granted. Arguably, the cogency of his argument and its appeal to other judges may have been increased if Yacoob $\mathrm{J}$ had clearly isolated the legal foundation of his reasoning (section 28(2) of the Constitution applied independently) and spelled out its legal content. However, identifying the legal content of section 28(2) of the Constitution when applied independently (and not together with other rights) would have been a major task for Yacoob $\mathrm{J}$ to have undertaken, given that clarity has been lacking in the Court's jurisprudence on this point. It is submitted, however, that had Yacoob J tried to do so, his judgment would have been more persuasive.

The above questions were dealt with in the context of the current interest in defining what constitutes a child rights approach or perspective to judging. But there are other ways in which Le Roux contributes to unwrapping the multi-dimensional concept of a children's rights perspective in judging. It arguably does so in two ways: first, by giving an indication of what may constitute the substantive features of such approach; and second, by illustrating some of the potential obstacles to employing it.

As far as the substantive aspects are concerned, Le Roux illustrates that taking a child rights approach may require the construction of legal arguments in support of a different legal treatment to be applied to children. This is most likely to occur in those areas of law where statutes, common law and case law have not yet been adapted to respond to children as different subjects of the law. ${ }^{92}$ Thus, a children's rights approach involves a search for legal grounds which justify a distinct legal treatment for children, which rests on the willingness of judges to interrogate the existing legal framework and its suitability to children, as done by Yacoob $\mathrm{J}$ in this case. The classic ground which has justified a different treatment for children has been their vulnerability, thus the attraction which the concept of best interests (constitutional, statutory, or common law) has exercised as a legal justification for the protection of such vulnerabilities. However, a case such as Le Roux exposes the danger of too quickly relying on a classic view of vulnerability. There, the majority did not see the children as vulnerable, and consequently made no effort to treat them differently in law. This stresses the need for a reassessment of how children's vulnerability is understood;

92 In areas of law such as family law, child protection or juvenile justice, the legal institutions have been adapted to a certain extent by the legislature, and thus the structure of reception for the rights of children is much more favourable. 
and, concomitantly, the need to explore other legal grounds to justify a different legal treatment for children.

In South Africa, the provision arguably most often relied on to secure a distinct legal treatment for children is section 28(2) of the Constitution, either by itself or in combination with other constitutional provisions. The limited support given to Yacoob J's judgment by the other members of the bench in Le Roux suggests that there may be limitations to this approach. ${ }^{93}$ When looked at in the context of the statements made by the majority, ${ }^{94}$ there may be an indication that the time is ripe to diversify the legal grounds on which a differential treatment of children is sought. Sections 9(1) (equal protection and benefit of the law) or 10 (dignity) of the Constitution, for example, are worth exploring as general frameworks.

The second way in which it is suggested that Le Roux contributes to understanding the elusive concept of a children's rights approach to judging is by unveiling some of the potential obstacles to it. Le Roux shows that there may be resistance to a children's rights approach, especially in areas of law where the rights of children have not yet penetrated. The majority judgment and some academic commentary suggest a certain reserve in relation to the rights of children making inroads in such areas of law, reflecting perhaps a perception that the rights of children may exist in a world of their own, somehow insular and not necessarily part of the legal mainstream.

The approaches taken to the conceptualisation of the legal issues in Le Roux by the majority and by Yacoob J respectively are in such stark contrast that the judgements do not speak to each other in relation to the rights of children. The split views of the judges and the type of critical comments attracted by Yacoob J's judgment expose the rift between "believers and non-believers"95 in the rights of children, between those for whom these rights are "self-evident"96 and those for whom they are not. This throws doubt over the consistency which can be expected from the courts in using a children's rights approach. It questions the strength of the actual support base for the rights of children even in legal systems where a strong formal basis exists. All of these ought to prompt an analysis into why it is that formally recognised rights generate such seemingly irreconcilable positions, both of which attract supporters.

93 Unfortunately, because the majority side-lined the rights of children, such weaknesses are not acknowledged in their judgement.

94 Which indicated a potential openness to other legal grounds to justify a differential legal treatment for children. See part 3.1 above.

95 Reynaert, Bouverne-De Bie and Vandevelde 2012 Int'I J Children's Rts 155.

96 Tobin 2013 Int'l J Children's Rts 397. 
It is possible that the insufficient theoretical clarity ${ }^{97}$ in children's rights may contribute to widely differing approaches in relation to their relevance for adjudication. Le Roux could be seen as an illustration of how the insufficient theoretical development of the rights of children has an impact on their protection. This was a difficult case in that it involved the horizontal application of an elusive constitutional provision (section 28(2) of the Constitution) in an area of law seldom exposed to the influence of the rights of children. The answers to the legal questions raised were not readily available in statutes, common law or case law. It is in the more general concepts or approaches in relation to the relationship between children and the law, and in relation to what justifies a special treatment for children, that the Court might have found some guidance. However, theoretical perspectives on children and their rights are perhaps stuck in an insufficiently sophisticated vulnerability refrain, unhelpful for the Court in a case like Le Roux.

The lack of sufficient clarity as to the theoretical foundation of the rights of children may also create a perception that such rights are exotic or esoteric, and difficult to fit into the legal mainstream. ${ }^{98}$ With the development of children's rights litigation, it can be said that such perceptions are incorrect. ${ }^{99}$ Regardless, they should not be too quickly dismissed, and instead should be used as starting points for critical reflection. One could, for example, reflect on whether the children's rights discourse might not have developed in a "bubble", away from the general legal discourse, and thus it might have itself contributed to a certain extent to generating such a perception. Further, one could reflect on whether this might not have resulted in a children's rights discourse oblivious to the tensions and idiosyncrasies which may be present in the operation of the rights of children.

Indeed, in children's rights literature it is sometimes difficult to distinguish between children's rights advocacy and scientific research. ${ }^{100}$ Much of the children's rights literature lacks a critical approach to such rights and the manner in which they articulate with the rest of the law. ${ }^{101}$ There may be an unspoken concern that critical views may undermine their still fragile and

$97 \quad$ Tobin 2013 Int'l J Children's Rts 397.

It is perhaps the estrangement between the children's rights discourse and the "hard law" of delict that made the penetration of the rights of children difficult in Le Roux. Allpay Consolidated Investment Holdings (Pty) Ltd v Chief Executive Officer of the South African Social Security Agency 20141 SA 604 (CC); Freedom Stationery (Pty) Ltd v MEC for Education, Eastern Cape 2011 JOL 26927 (E); Van der Burg.

100 As acknowledged by Hanson "Does Practice Also Work in Theory?" 636.

101 Instead, arguments are made that children's rights ought to be given effect, or even prevail. But for acknowledgement of the dangers of "rights talk" see Fortin Children's Rights and the Developing Law 9; Human "Theory of Children's Rights" 252. 
underdeveloped edifice. The reverse, however, may be equally dangerous: the development of a parallel legal and academic discourse, estranged from the legal mainstream, and perceived as exotic and capricious, and whose logic is understood by only a few. The appeal that children's rights developed in this way would hold for judges, legal practitioners or outsiders is doubtful, and so is the likelihood of a children's rights approach being consistently followed.

A robust critical discourse within the children's rights research community needs to develop so that these rights grow by confronting and addressing difficulties, contradictions and tensions. Arising from this writer's reflections on Le Roux, and thus by no means exhaustive, two possible suggestions for the development of a more critical children's rights discourse can be made. For example, judgments which are favourable to children should not be unreservedly endorsed by children's rights supporters simply because of their child-friendly outcome, if the legal reasoning is insufficiently persuasive. Criticism from within the children's rights community may contribute to refining the children's rights usage in similar subsequent cases, increasing the cogency of the legal reasoning and, hopefully, resulting in a wider and more sustainable judicial support for a children's rights approach. Second, the reference framework for children's rights research should be extended, and children's rights researchers should inquire more often into the difficulties of responding positively to children's rights arguments in the context of the existing legal framework, which as seen in Le Roux may not have been transformed by the constitutional rights of children. It is not argued here that one needs to take a defeatist approach and acquiesce to the status quo. Instead, what is proposed is that when children's rights arguments are not successful, the position of the decisionmaker or opinion-holder is not dismissed as opacity to the rights of children. Rather, as children's rights researchers, we should be asking ourselves if there are legitimate reasons for which the children's rights arguments have not been successful. Cogent concerns about the operation of the rights of children should be used as clues to help understand the obstacles to a wider adherence to "thinking legal" in a children's rights framework. A better understanding of such concerns by the children's rights researchers would enable them to construct more persuasive arguments, which would resonate not only with the children's rights "converts" but with a wider legal audience.

The observations made in this contribution in relation to defining a children's rights approach to judging arise from a specific case, in a specific area of law and in a particular legal system. A children's rights approach may look different in a case concerning children indirectly, in a family law context or in a different legal system. For example, in a different legal system, where 
judges may not be constitutionally entitled to question the law, a children's rights approach may rest on different legal institutions and entail different things. However, there is a possibly universal foundation to a children's rights approach to judging, which may be pursued in many different ways, across diverse legal systems - that is, an alertness to children's uniqueness as subjects of the law, and the cultivation of a judicial mind open to exploring or developing the law in search of means to respond to that uniqueness.

\section{Bibliography}

\section{Literature}

Bonthuys 2006 IJLPF

Bonthuys E "The Best Interests of Children in the South African Constitution" 2006 IJLPF 23-43

Buthelezi 2012 Obiter

Buthelezi M "In Dissent: A Critical Review of the Minority Judgment of Yacoob J in Le Roux v Dey 2011 (3) SA 274 (CC)" 2012 Obiter 719-731

Campbell 2011 SALJ

Campbell J "Pleading Meaning in Defamation Cases: Le Roux v Dey" 2011 SALJ 419-427

Couzens 2013 SALJ

Couzens $\mathrm{M}$ "The Constitutional Court Consolidates its Child-Focused Jurisprudence: The Case of $C$ and Others $v$ Department of Health and Social Development, Gauteng and Others" 2013 SALJ 672-687

Couzens "Contribution of the South African Constitutional Court"

Couzens M "The Contribution of the South African Constitutional Court to the Jurisprudential Development of the Best Interests of the Child" in Diduck A, Peleg N and Reece $\mathrm{H}$ (eds) Law in Society: Reflections on Children, Family, Culture and Philosophy. Essays in Honour of Michael Freeman (Brill Leiden 2015) 521-549

Dixon and Nussbaum 2011-2012 Cornell L Rev

Dixon R and Nussbaum M "Children's Rights and Capabilities Approach: The Question of Special Priority" 2011-2012 Cornell L Rev 549-593

Fagan 2011 SALJ

Fagan A "The Constitutional Court Loses its (and Our) Sense of Humour: Le Roux v Dey" 2011 SALJ 395-407 
Fortin Children's Rights and the Developing Law

Fortin J Children's Rights and the Developing Law (Cambridge University Press Cambridge 2009)

Hanson "Does Practice Also Work in Theory?"

Hanson K "Does Practice Also Work in Theory?" in Allen A et al (eds) The UN Children's Rights Convention: Theory Meets Practice (Intersentia Antwerp 2007) 633-646

Human "Theory of Children's Rights"

Human S "The Theory of Children's Rights" in Boezaart T (ed) Child Law in South Africa (Juta Claremont 2009) 243-262

Mills 2014 SALJ

Mills $L$ "Failing Children: The Courts' Disregard of the Best Interests of the Child in Le Roux v Dey" 2014 SALJ 847-864

Neethling and Potgieter 2011 Obiter

Neethling $J$ and Potgieter JM "Defamation of School Teachers by Learners: Le Roux v Dey 20113 SA 274 (CC)" 2011 Obiter 721-730

Reynaert, Bouverne-De Bie and Vandevelde 2012 Int'I J Children's Rts Reynaert D, Bouverne-De Bie M and Vandevelde S "Between 'Believers' and 'Opponents': Critical Discussions on Children's Rights" 2012 Int'l J Children's Rts 155-168

Schäfer "Division E: Young Persons"

Schäfer L "Division E: Young Persons" in Clark B Family Law Service (LexisNexis Durban, last updated October 2017)

Skelton "Constitutional Protection of Children's Rights"

Skelton A "Constitutional Protection of Children's Rights" in Boezaart T (ed) Child Law in South Africa (Juta Claremont 2009) 265-290

Skelton "South Africa"

Skelton A "South Africa" in Liefaard T and Doek JE (eds) Litigating the Rights of the Child: The UN Convention on the Rights of the Child in Domestic and International Jurisprudence (Springer Dordrecht 2015) 13-30

Sloth-Nielsen and Kruuse 2013 Int'I J Children's Rts

Sloth-Nielsen $\mathrm{J}$ and Kruuse $\mathrm{H}$ "A Maturing Manifesto: The Constitutionalisation of Children's Rights in South African Jurisprudence 2007-2012" 2013 Int'l J Children's Rts 646-678 
Stalford, Hollingsworth and Gilmore Rewriting Children's Rights Judgments Stalford $\mathrm{H}$, Hollingsworth $\mathrm{K}$ and Gilmore S Rewriting Children's Rights Judgments: From Academic Vision to New Practice (Hart Oxford 2017)

Stubbs 2013 Stell LR

Stubbs M "In Loco Parentis Le Roux v Dey [Discussion of Le Roux v Dey (Freedom of Expression Institute and Another as Amici Curiae) 20113 SA 274 (CC)]" 2013 Stell LR 377-390

Tobin 2013 Int'l J Children's Rts

Tobin J "Justifying Children's Rights" 2013 Int'I J Children's Rts 395-441

Tobin "Development of Children's Rights"

Tobin J "The Development of Children's Rights" in Young L, Kenny MA and Monahan G (eds) Children and the Law in Australia $2^{\text {nd }}$ ed (LexisNexis Butterworths Chatswood 2016) 25-54

\section{Case law}

$A D$ v DW (Centre for Child Law as Amicus Curiae; Department for Social Development as Intervening Party) 20083 SA 183 (CC)

Allpay Consolidated Investment Holdings (Pty) Ltd v Chief Executive Officer of the South African Social Security Agency 20141 SA 604 (CC)

C v Department of Health and Social Development, Gauteng 20122 SA 208 (CC)

Centre for Child Law v Minister of Justice and Constitutional Development 20096 SA 632 (CC)

Christian Education South Africa v Minister of Education 200010 BCLR 1051 (CC)

De Reuck v Director of Public Prosecutions (Witwatersrand Local Division) 200312 BCLR 1333 (CC)

Director of Public Prosecutions, Transvaal $v$ Minister of Justice and Constitutional Development 20094 SA 222 (CC)

Freedom Stationery (Pty) Ltd v MEC for Education, Eastern Cape $2011 \mathrm{JOL}$ $26927(\mathrm{E})$

J v National Director of Public Prosecutions 20142 SACR 1 (CC) 
Khumalo v Holomisa 20028 BCLR 771 (CC)

Le Roux v Dey (Freedom of Expression Institute and Restorative Justice Centre as Amici Curiae) 20113 SA 274 (CC)

MEC for Education: KwaZulu-Natal v Pillay 20081 SA 474 (CC)

S v M (Centre for Child Law as Amicus Curiae) 20083 SA 232 (CC)

Teddy Bear Clinic for Abused Children $v$ Minister of Justice and Constitutional Development 20142 SA 168 (CC)

Van der Burg v National Director of Public Prosecutions 20122 SACR 331 (CC)

YG v S 2017 ZAGPJHC 290 (19 October 2017)

\section{Legislation}

Child Justice Act 75 of 2008

Children's Act 38 of 2005

Constitution of the Republic of South Africa, 1996

\section{International instruments}

African Charter on the Rights and Welfare of the Child (1990)

UN Convention on the Rights of the Child (1989)

\section{Internet sources}

De Vos 2011 http://constitutionallyspeaking.co.za/is-the-reasonableperson-a-homophobic-prude/

De Vos P 2011 Is the Reasonable Person a Homophobic Prude? http://constitutionallyspeaking.co.za/is-the-reasonable-person-ahomophobic-prude/ accessed 30 January 2016

Milo and Palmer 2011 http://www.thedailymaverick.co.za/article/2011-0317-analysis-schoolboy-scandals-and-defamation-in-sa-quo-vadis Milo D and Palmer G 2011 Schoolboy Scandals and Defamation in SA. Quo Vadis?" http://www.thedailymaverick.co.za/article/2011-03-17-analysisschoolboy-scandals-and-defamation-in-sa-quo-vadis accessed 24 August 2017 


\section{List of Abbreviations}

Cornell L Rev

CRJP

FXI

IJLPF

Int'I J Children's Rts

RJC

SALJ

SCA

Stell LR
Cornell Law Review

Children's Rights Judgments Project

Freedom of Expression Institute

International Journal of Law, Policy and the

Family

International Journal of Children's Rights

Restorative Justice Centre

South African Law Journal

Supreme Court of Appeal

Stellenbosch Law Review 